\title{
OS III CONDES DE MIRANDA Y SUS FUNDACIONES RELIGIOSAS: ENTRE EL RECUERDO FAMILIAR Y LA EXALTACIÓN DEL LINAJE
}

JUAN ESCORIAL ESGUEVA

Departamento de Historia del Arte / Bellas Artes. Universidad de Salamanca juanescorial@usal.es

Resumen: Francisco de Zúñiga y Avellaneda, III conde de Miranda, y su esposa, María Enríquez de Cárdenas, desarrollaron, a lo largo del primer tercio del siglo XVI, un importante conjunto de actuaciones entre las cuales, sus fundaciones religiosas, destacan de forma especial. Las distintas promociones que el matrimonio llevó a cabo en la villa burgalesa de Peñaranda de Duero y el cercano monasterio de Santa María de La Vid, donde se ubicaría su sepultura, contribuyeron a definir la imagen con la que se quería identificar al linaje.

Palabras clave: condes de Miranda / arquitectura / Burgos / siglo XVI / Renacimiento.

\section{THE III COUNTS OF MIRANDA AND THEIR RELIGIOUS FOUNDATIONS: BETWEEN FAMILY MEMORIES AND LINEAGE EXALTATION}

Abstract: Francisco de Zúñiga y Avellaneda, 3rd count of Miranda, and his wife, María Enríquez de Cárdenas, developed, during the first third of the 16th century, an important set of activities among wich their religious foundations stand out in a special way. The different promotions that the marriage carried out in Peñaranda de Duero (Burgos) and the construction of the main chapel of the monastery of Santa María de La Vid, where their grave would be located, contributed to define the new image with which they wanted to identify their lineage.

Key words: counts of Miranda / architecture / Burgos / 16th century / Renaissance.

Durante el quinientos, las principales casas nobiliarias del complejo panorama castellano contribuyeron a la financiación y apoyo de relevantes fundaciones religiosas que, desde sus ámbitos de influencia, permitían acrecentar el valor y la preeminencia de sus promotores. A ello se sumaba el deseo de perpetuar su memoria, pero también el anhelo por construir una imagen que sirviera para engrandecer el linaje al que pertenecían, contribuyendo a renovar la consideración de la nobleza, tanto por su vocación como protectores de estos establecimientos religiosos, como por situarse en ellos un buen número de sus enterramientos familiares. ${ }^{1}$
Las distintas estrategias del estamento nobiliario sirvieron a las antiguas casas monásticas y conventuales para redefinir sus fábricas y dotarlas de una imagen renovada que, sin olvidar sus orígenes, permitía identificarlas con el nuevo tiempo. En otras ocasiones, estas familias asentaron los cimientos de distintas comunidades religiosas e, incluso, de instituciones asistenciales que, alentadas al calor de distintas órdenes religiosas, buscaban actualizar las iniciativas propias de la clase nobiliaria respecto a los ámbitos sagrados, tanto a través de la oración como de la atención a los más desfavorecidos. ${ }^{2}$ Estas circunstancias facilitaron su

\footnotetext{
* Fecha de recepción: 15 de enero de 2019 / Fecha de aceptación: 5 de abril de 2019.

1 Sobre ello, vid. YARZA LUACES, Joaquín, 1988, pp. 67-91. BANGO TORVISO, Isidro, 1992, pp. 93-132. PEREDA ESPESO, Felipe, 1999, pp. 313-324.

2 ATIENZA LÓPEZ, Ángela, 2010, pp. 235-269.
} 
uso como escenarios en los que hacer presente el papel desempeñado en vida por sus patronos y reforzar, de forma paralela, el prestigio social de aquellas familias capaces de desarrollar un proyecto de estas características. ${ }^{3}$

Todo ello ayudó a conformar, a lo largo de esta centuria, un renovado carácter que, dentro del ideario colectivo que la nobleza venía construyendo desde época medieval, ${ }^{4}$ situaba en la magnificencia de las nuevas propuestas arquitectónicas su principal apuesta. Estas, presididas por las representaciones heráldicas de los diversos entronques genealógicos, permitirían perpetuar el recuerdo del pasado familiar, hacerlo presente a su descendencia $y$, en definitiva, delimitar su dimensión más piadosa. ${ }^{5}$

En este contexto, el ámbito burgalés jugó un papel de especial relevancia en la definición de la imagen de la nobleza quinientista, como consecuencia del profundo dinamismo que había caracterizado a la vieja Caput Castellae en los compases finales de la Baja Edad Media. ${ }^{6}$ Las primeras familias del estamento nobiliario, encabezadas por los II condes de Haro, iniciaron profundas transformaciones en sus distintos patronatos, que pasarían a constituir un signo permanente de su posición. ${ }^{7}$ Su descendencia asumió la continuidad de estos proyectos, comprendiendo el modo en que el legado de sus antepasados se perpetuaba a través de sus obras y cómo sus propias actuaciones renovaban el espíritu de estos.

Por ello, algunos de sus herederos emprendieron iniciativas en las que son evidentes las citas a las fundaciones de sus predecesores, como testimonian, de forma especialmente elocuente, sus respectivas capillas funerarias. ${ }^{8}$ De hecho, el influjo de la capilla de la Purificación de la catedral burgalesa terminó conformando un signo identitario vinculado al linaje de los Velasco y que serviría tanto para honrar a sus fundadores como para proclamar el papel que sus descendientes asumían como herederos de esta antigua casa castellana. ${ }^{9}$
El III conde de Miranda, Francisco de Zúñiga y Avellaneda, no se mantuvo al margen de esta dinámica y emprendió, al igual que otros familiares, diversas iniciativas en las que la herencia de los Velasco -a través de su madre, Catalina, hija de los II condes de Haro- se integraría con otras aportaciones. Entre ellas, destaca la influencia de su esposa, María Enríquez de Cárdenas, que jugó un papel de especial relevancia en algunas actuaciones. $^{10}$

El matrimonio lograría configurar, a través de diferentes iniciativas, una identidad propia que pasaría a representar al linaje de los Zúñiga, sin olvidar, no obstante, el legado adquirido por ambos cónyuges en relación a su origen familiar. ${ }^{11}$ Estas tuvieron como protagonistas a la villa burgalesa de Peñaranda de Duero y al cercano monasterio de Santa María de La Vid, en los que asentarían las bases de un complejo programa constructivo que no podrían ver concluido pero que sirvió como referente y ejemplo para sus sucesores ${ }^{12}$ (Fig. 1).

\section{Espacios y memoria: del legado familiar a la promoción nobiliar}

Si bien los III condes de Miranda fueron quienes, a través de sus promociones, definieron las claves principales de la construcción de la imagen familiar, estas no pueden explicarse sin tener en cuenta el legado de sus antepasados y su propia trayectoria vital, aunque su huella se haya diluido con el paso del tiempo. ${ }^{13}$ No obstante, parece evidente que sus predecesores en el título apoyaron y protegieron diversas fundaciones religiosas que, en el contexto del Duero burgalés, adquieren un papel determinante y preludian un largo proceso de promoción artística estrechamente ligado a los intereses de la casa de Miranda y a su proyección pública.

Durante el último tercio del siglo $\mathrm{XV}$, los miembros más eminentes de la familia tomaron en consideración a dos de las casas religiosas más relevantes del entorno ribereño burgalés -el convento

\footnotetext{
3 ATIENZA LÓPEZ, Ángela, 2008c, p. 189.

${ }^{4}$ MARTíneZ-BURgos GARCíA, Palma, 1990, pp. 193-194. SORIA MESA, Enrique, 2007, pp. 265-266.

5 ALONSO RUIZ, Begoña, 2012, 34, p. 235.

6 PAYO HERNANZ, René Jesús y MATESANZ DEL BARRIO, José, 2015.

7 Sobre ello, vid. PAULINO MONTERO, Elena, 2014, pp. 120-126.

8 ALONSO RUIZ, Begoña, 2005, pp. 121-206.

9 ALONSO RUIZ, Begoña, 2005, pp. 132-137.

10 Así se ha puesto de manifiesto en ZAPARAín YÁÑEZ, María José, 2013, pp. 280-289.

11 ZAPARAín YÁÑEZ, María José, 2013, pp. 286, 288.

12 ZAPARAÍN YÁÑEZ, María José y ESCORIAL ESGUEVA, Juan, 2018, pp. 620-621; 2019, pp. 137-146.

13 Sobre la génesis de la casa de Miranda, vid. PERIBÁÑEZ OTERO, Jesús G., 2016, pp. 108-128.
} 
franciscano de Domus Dei de La Aguilera y el monasterio premonstratense de Santa María de La Vid-, donde fueron sepultados, respectivamente, Diego López de Zúñiga y Aldonza de Avellaneda, I condes de Miranda, y -sus sucesores en el títuloPedro de Zúñiga y Catalina de Velasco. ${ }^{14}$ La elección no era casual, pues el primero se encontraba dentro de su dominio nobiliar y el segundo, cabeza de un significativo señorío monacal en decadencia, se situaba en los límites territoriales de la villa de Peñaranda de Duero, constituida entonces como epicentro de su señorío.

Esta circunstancia fue aprovechada por los Zúñiga para ampliar su control sobre el territorio y determinar su preeminencia respecto al resto de actores que tenían un marcado interés por el dominio del contexto ribereño. ${ }^{15}$ Sin embargo, no se conocen promociones específicas de los primeros titulares del condado de Miranda en estas fundaciones aunque, sus continuadores, Francisco de Zúñiga y María Enríquez de Cárdenas, ${ }^{16}$ se sirvieron de la experiencia del pasado y emprendieron una política de dominio sobre ambas casas, convirtiéndolas en elementos inherentes al linaje Zúñiga y copartícipes en la construcción de su propia identidad. ${ }^{17}$

El cenobio franciscano, por su parte, había mantenido desde su fundación en 1404 un estrecho vínculo con algunas eminentes familias de la nobleza burgalesa que se mantuvieron próximas al ideario de la reforma villacreciana en la que se enmarcaba esta casa. Dicha reforma tuvo, en la figura de fray Pedro Regalado, su principal protagonista, ${ }^{18}$ cuya fama de santidad atrajo a la condesa de Haro, que sufragó el bello sepulcro de alabastro que acogía sus restos. ${ }^{19}$ Las diversas transformaciones que ha sufrido el edificio han borrado todo vestigio arquitectónico tardomedieval y ello impide conocer las características primigenias del conjunto, pero los diferentes testimonios documentales indican que

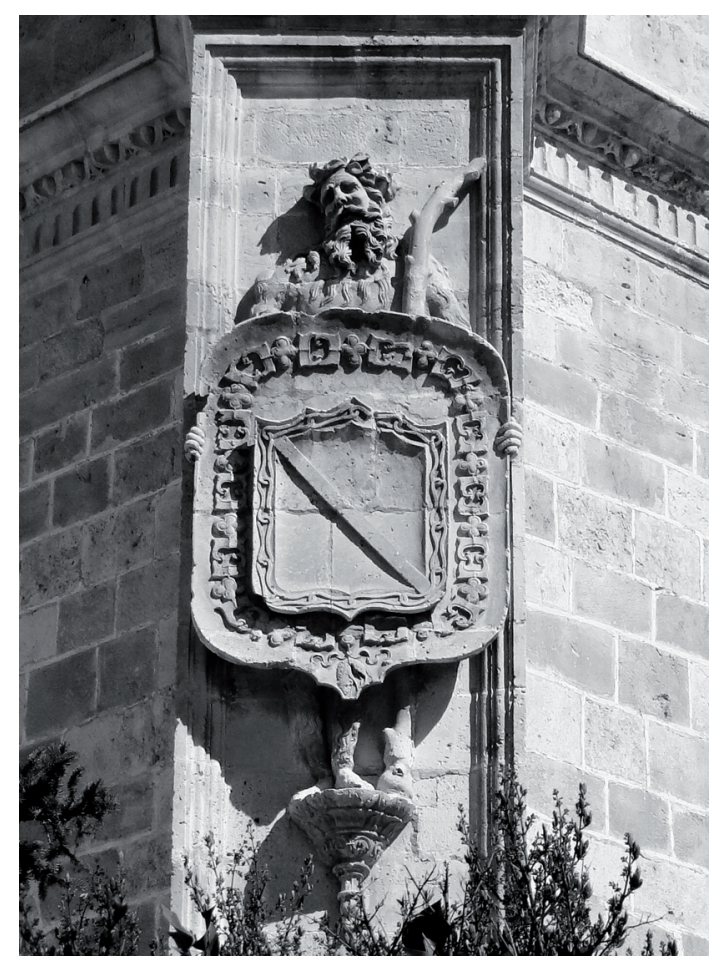

Fig. 1. Escudo de Francisco de Zúñiga y Avellaneda, III conde de Miranda, en la cabecera de la iglesia del monasterio de Santa María de La Vid (Burgos). Fotografía del autor.

fue el ámbito elegido por varios de los vástagos de los II condes de Miranda -descendientes también de la condesa de Haro- para ubicar su enterramiento, perpetuando así los vínculos familiares en este establecimiento religioso y siguiendo el ejemplo de los condes de Castro, que habían situado en una de sus capillas su propio panteón. ${ }^{20}$

Por ello, en 1506, Aldonza de Zúñiga, esposa del VI conde de Salvatierra, ${ }^{21}$ manifestó su intención

\footnotetext{
${ }^{14}$ Algunas publicaciones han venido defendiendo diversos emplazamientos para el enterramiento de los I y II condes de Miranda, arrastrando el error planteado en PELLICER DE OSSAU Y TOVAR, José, 1668, fol. 59v. Sobre ello, cfr. AHNob [Archivo Histórico de la Nobleza]. Frías, c. 888, d. 11, fol. 8v.

15 Sobre este tema, vid. PERIBÁÑEZ OTERO, Jesús G., 2010, pp. 20-21.

${ }^{16}$ Francisco de Zúñiga y Avellaneda sucedió en el título a su padre tras su muerte en 1492. El matrimonio con María Enríquez de Cárdenas, hija de Gutierre de Cárdenas y María Enríquez, fue concertado por la condesa viuda, Catalina de Velasco, tres años después. Las capitulaciones matrimoniales en AHNob, Baena, c. 224, d. 86; c. 251, d. 21.

17 Sobre la construcción de la identidad nobiliar, vid. QUINTANILLA RASO, María Concepción, 2007, pp. 958-971.

18 ZAPARAÍN YÁÑEZ, María José, 2016, pp. 236-237.

19 Entre otros, PEREDA ESPESO, Felipe, 2005, pp. 37-40 y ZAPARAíN YÁÑEZ, María José, 2016, pp. 227-237.

20 Una de las capillas del claustro albergaba, entre otros, los enterramientos de Diego Gómez de Sandoval y Beatriz de Avellaneda, I condes de Castro, Catalina de Mendoza, I marquesa de Denia o Catalina de Zúñiga y Avellaneda, III marquesa de Denia e hija de los III condes de Miranda, según CARRIÓN GONZÁLEZ, Luis, 1930, pp. 288-292.
}

${ }^{21}$ ARChV [Archivo de la Real Chancillería de Valladolid], Registro de ejecutorias, c. 200, 26. 
de que, tras su fallecimiento, fuese sepultada en este convento, expresando, del mismo modo, que el cuerpo de su hijo Vela fuera también trasladado a La Aguilera. ${ }^{22}$ En 1512, su hermano Pedro de Zúñiga, que había ocupado el cargo de corregidor de Valladolid, declaraba que quería ser enterrado junto a la tumba de doña Aldonza, bajo una "...losa Ilana...", ${ }^{23}$ pero dejando a su esposa, Aldonza de Velasco, sobrina del I conde de Siruela, la obligación de trasladar sus restos a otro lugar al cabo de dos años, ${ }^{24}$ tal vez con la intención de que esta hiciera posible la construcción de un espacio funerario propio.

Sin embargo, la pretensión de Aldonza de Velasco era bastante más ambiciosa puesto que quería fundar un nuevo convento "...de frayles de la orden de Santo Domingo o Sant Agustín..." en Peñaranda de Duero, para poder enterrarse junto a su esposo en la capilla mayor del mismo. ${ }^{25}$ De este modo se daban los primeros pasos para el establecimiento en la villa burgalesa de una casa religiosa que materializara la significación que, a partir del último tercio del siglo $\mathrm{XV}$, comenzaba tener la localidad en la construcción de la imagen de la casa de Miranda. El afán de superación del pasado y la necesidad de identificarse con determinados hitos arquitectónicos y devocionales parece que está detrás de esta decisión. El patronato religioso y, particularmente, la fundación de un convento, aparte de cubrir las necesidades piadosas de la nobleza, suponían la consolidación de su poder y una justificación del papel social representado, ${ }^{26}$ al tiempo que incrementaban la proyección personal y contribuían al mantenimiento de la memoria de sus promotores. ${ }^{27}$
Aldonza de Velasco no pudo hacer frente a la realización material del convento y, ni siquiera, llevar a cabo su fundación, por lo que se vio obligada a recurrir a su cuñado, el III conde de Miranda, para poder proseguir este ansiado proyecto. Sin embargo, don Francisco no aceptó todas las condiciones que se habían planteado inicialmente y, según consta en un acuerdo entre ambos, logró que "...el dicho monasterio no fuese de frayles sino de monjas, y de la Orden de la Concebçión...". 28

Este cambio puede tratarse, seguramente, de un requisito impuesto por su esposa, que tenía una estrecha vinculación con esta orden religiosa. No en vano, su madre, Teresa Enríquez, había fundado un convento de franciscanas concepcionistas en Torrijos ${ }^{29}$ e incluso alguna de sus hijas hizo profesión en el mismo, ${ }^{30}$ en el marco del auge de las corrientes inmaculistas durante la primera mitad del $X V I^{31}$ que se consolidaría, con especial fuerza, entre las devociones femeninas de la familia.

Los condes de Miranda emprendían, a través de esta fundación y del palacio familiar que estaban construyendo en la villa burgalesa, ${ }^{32}$ diferentes proyectos que buscaba consolidar el papel de la familia en la capital de su señorío. Con ello pretendían modernizar su antigua estructura medieval, integrando en su trama urbana nuevos edificios que se identificaban directamente con su labor de promoción.

Por ello, Francisco de Zúñiga aceptó construir el convento, reservando el espacio de la capilla mayor de su iglesia para el enterramiento de su hermano Pedro y su esposa Aldonza. ${ }^{33}$ Sin embargo, esta última no pudo cumplir con las obligaciones

22 AHNob, Frías, c. 601, d. 8, fol. 1; d. 9, fol. 1v.

23 ACPD [Archivo del Convento de la Purísima Concepción de Peñaranda de Duero], leg. 6, primer instrumento. Esta noticia había sido dada a conocer -confundiendo a Pedro de Zúñiga con su hermano Juan- en: JIMENO, Pascual Domingo, 1966, p. 103. Aprovecho para expresar mi gratitud hacia la comunidad del convento por las facilidades para el estudio del edificio y la consulta de sus fondos documentales, de forma especial a su abadesa, sor Celina Arranz.

24 ACPD, leg. 6, primer instrumento.

25 ACPD, leg. 6, tercer instrumento.

26 ATIENZA LÓPEZ, Ángela, 2008a, pp. 79-82; 2008b, p. 80.

27 Sobre ello, URQUíZAR HERRERA, Antonio, 2007, p. 79.

28 ACPD, leg. 6, quinto instrumento.

29 Recogido en ZAPARAín YÁÑEZ, María José, 2013, p. 286. Sobre el convento, vid. CASTRO Y CASTRO, Manuel de, 1991; 1992. Para una visión de contexto, ATIENZA LÓPEZ, Ángela, 2008c, pp. 118-120.

30 AHNob, Frías, c. 888, d. 11, fol. 25v. ADBu [Archivo Diocesano de Burgos], Peñaranda de Duero, leg. 10, Bullas y papeles originales con los autos que tocan a la jurisdicción desta collegial de Peñaranda, fol. 29v.

31 Sobre ello, RUIZ-GÁLVEZ PRIEGO, Estrella, 2006, pp. 291-310; 2008, pp. 197-241.

32 LAMPÉREZ Y ROMEA, Vicente, 1912, pp. 146-151. CARAZO LEFORT, Eduardo, 1997, pp. 505-544. MARÍAS, 1998 , pp. $291-292$. MARTÍNEZ MONTERO, Jorge, 2005, pp. 75-87.

33 AHNob, Frías, c. 539, d. 39, fol. 12. AMAD [Archivo Municipal de Aranda de Duero], caja 26, leg. 1, fols. 169-169v. 
acordadas y precisó sucesivas prórrogas para pagar la parte que le correspondía en la construcción del mismo. ${ }^{34}$ Finalmente serían los III condes quienes harían posible el desarrollo de su fábrica, como atestigua el testamento conjunto que redactaron en $1533 .{ }^{35}$

De forma paralela al desarrollo de esta fundación, los III condes decidieron "...hazer y labrar [...] un hospital donde se curen y acojan y apiaden pobres enfermos...", bajo la advocación de la Piedad. ${ }^{36}$ El matrimonio concertó en vida cómo se financiaría la construcción de ambos complejos, determinando para ello que el conde pagaría las obras del convento a través de sus rentas y que sería su esposa la encargada de promover la realización del hospital, reservando para su dotación los bienes comunes del matrimonio. ${ }^{37}$

Eligieron para su ubicación el flanco oriental de la localidad, fuera del recinto amurallado, ocupando un sector urbano próximo al cauce del río. Tanto la cronología como el desarrollo de las obras ofrecen numerosas dudas, pero parece claro que su planteamiento arquitectónico ya estaba desarroIlado a principios de la década de 1530. Los III condes, en su testamento de 1533, ordenaban a sus sucesores que debían construir los dos edificios "...conforme a las traças y a como estuvieren erigidas dichas obras...", 38 aunque no consta quién pudo ser el autor de su diseño, cuya conclusión no tuvo lugar hasta después de la muerte de los cónyuges.

Sin embargo, puede evidenciarse que algunos de sus elementos fueron edificados simultáneamente, como sus amplios patios cuadrangulares de dos al- turas, construidos con una excelente cantería y un depurado tratamiento de los detalles ornamentales. ${ }^{39}$ Los espacios dedicados al culto están situados en los ángulos exteriores de los dos inmuebles, siguiendo la orientación canónica. En el caso del hospital, la capilla ofrece una imagen muy transformada, pero al exterior presenta varios contrafuertes que, posiblemente, indiquen la existencia de una bóveda de crucería en la obra inicial, hoy desaparecida. En el convento, la iglesia ocupa todo el flanco norte del edificio, mostrando dos espacios claramente diferenciados. Por un lado, la capilla mayor, cubierta por una sencilla bóveda de terceletes, y una larga nave con una cuidada armadura de madera, similar a las que cubren otras estancias del inmueble (Fig. 2).

La imagen actual de ambos conjuntos ${ }^{40}$ poco tiene que ver con el seguimiento de un plan rector desde su inicio, testimoniando el lento avance de las obras y el hecho de que estas debieron dilatarse en el tiempo durante varias décadas. ${ }^{41}$ Además, en los dos casos, las múltiples transformaciones impiden una reconstrucción del resto de espacios que compusieron su distribución original, pero parece claro que en los dos edificios se tuvo muy en cuenta su proximidad al entorno natural y se les dotó de ricas huertas, prestando especial atención a la traída de aguas para su servicio. ${ }^{42}$

La bula de fundación del convento fue otorgada por el papa Paulo IV en $1558^{43}$ y su hijo, Francisco de Zúñiga, entonces IV conde de Miranda, fue el responsable de la elección de la abadesa, ${ }^{44}$ confiando este cargo a su hermana Ana, que sería conocida como Ana de Cristo, ${ }^{45}$ que llegó a Peñaran-

\footnotetext{
${ }^{34}$ ACPD, legs. 8, 9, 10.

35 AHNob, Frías, c. 888, d. 11, fols. 10-10v. El propósito quedó ratificado en el testamento de la III condesa, de 1544. ADBu, Peñaranda de Duero, leg. 10. Bullas... doc. cit, fols. 4-4v.

36 AHNob, Frías, c. 888, d. 11, fol. 17v. Se seguía, de nuevo, el ejemplo de los progenitores de la condesa, que habían fundado sendos hospitales en Torrijos. ZAPARAíN YÁÑEZ, María José, 2013, pp. 281 y 287.

37 AHNob, Frías, c. 888, d. 11, fol. 17v. Cabe señalar, también, que su hija, Mencía de Mendoza, fundó un hospital, dedicado a la Magdalena, en Fuentiduña. Sobre ello, vid. Archivo General de Simancas, CME, 99, 42.

38 AHNob, Frías, c. 888, d. 11, fols. 9v-10, 17v. El matrimonio legó un importante número de muebles para su dotación, dedicando especial atención a la capilla del Hospital a la que, aparte de piezas de orfebrería y ropas litúrgicas, destinaron dos retablos, hoy desaparecidos. AHNob, Frías, c. 888, d. 11, fol. 10.

39 ZAPARAÍN YÁÑEZ, María José, 2013, pp. 286-287.

40 Sobre el convento, vid. LÓPEZ CUÉTARA, José Manuel, 1993, p. 313.

41 En torno a 1573 se contratan diversas labores de carpintería en el edificio, por lo que su culminación se llevaría a cabo próxima a esta fecha. AHPBu [Archivo Histórico Provincial de Burgos], Prot. 5254, fols. 425 y ss.

42 AHPBu, Prot. 5251, fols. 618-620.

43 ACPD, leg. 1. También en AHPBu, Prot. 10721, fols. 388-389v. El templo fue consagrado el 30 de marzo de 1558 por el obispo de Salamina, Francisco de Salazar. ACPD, leg. 5.

44 AHPBu, Prot. 10721, fols. 373-376, 383-387v.

45 LLAGAS, Ángela de las, 1923, p. 54.
} 


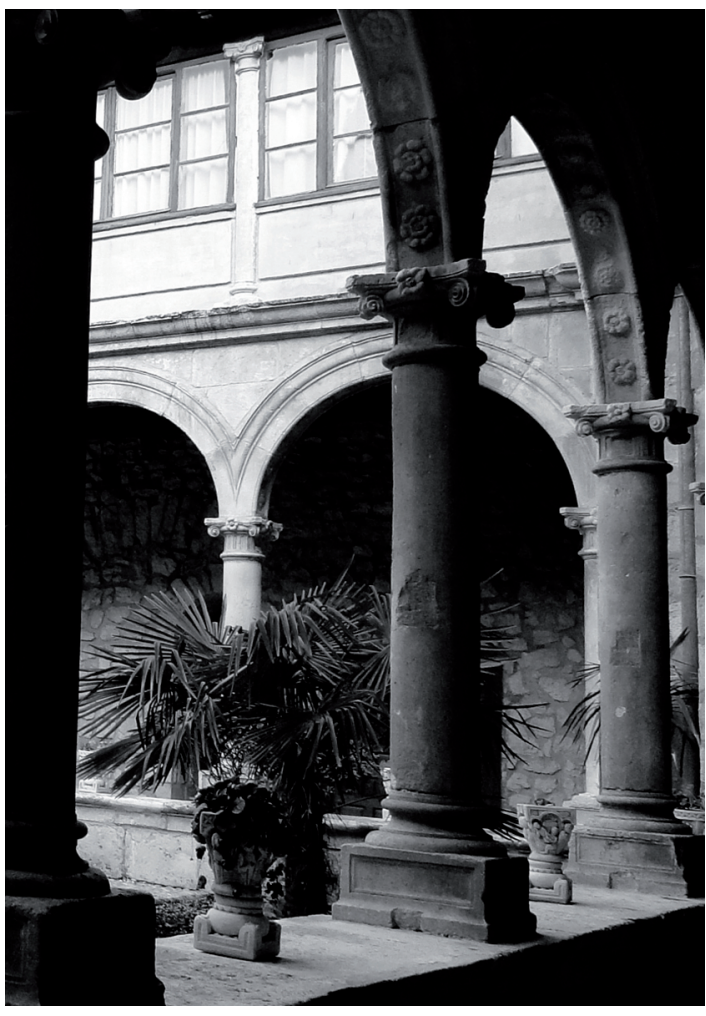

Fig. 2. Claustro del convento de Nuestra Señora de la Concepción de Peñaranda de Duero (Burgos). Fotografía del autor.

da de Duero junto a otras religiosas procedentes del convento de Torrijos ese mismo año. ${ }^{46} \mathrm{~A}$ partir de este momento, otras mujeres descendientes de los III condes profesaron en esta casa, como sus nietas, Catalina de Zúñiga (1558) ${ }^{47}$ y Magdalena de Bazán (1560), ${ }^{48}$ o su biznieta, Brianda de Bazán (1574).49 Los diferentes condes no olvidaron el convento y continuaron promoviendo diversas obras en él, sirviéndose de su patronato para potenciar su imagen e incorporar sus armas en los elementos más significativos. ${ }^{50}$ El hospital, por su parte, ya estaba abierto en 1558 y el IV conde de Miranda, como patrono del mismo, se ocupó de dictar diversas instrucciones que aseguraran su correcto funcionamiento. ${ }^{51}$

Con estas intervenciones los III condes y sus sucesores en el título culminaban el proceso de transformación del sector de levante de la localidad que, junto a las modificaciones urbanas que exigió la construcción del palacio familiar, dotaban a la villa de una nueva imagen con la que se evidenciaba el dominio de la casa de Miranda.

\section{Un ámbito para el recuerdo: el monasterio de Santa María de la Vid}

Las pretensiones de los III condes de Miranda no se limitaron al entorno urbano de Peñaranda de Duero sino que buscaron proyectar su imagen en el cercano monasterio premonstratense de Santa María de La Vid en el que, tras una larga génesis, configuraron una capilla con vocación de panteón familiar que se convertiría en un símbolo inseparable del linaje de los Zúñiga (Fig. 3).

Este monasterio, fundado a mediados del siglo XII y vinculado desde sus inicios con la monarquía castellana, ${ }^{52}$ era una de las abadías más poderosas de la Orden de Premontré en Castilla. Sin embargo, la relación de los antepasados de los Miranda con La Vid fue muy tímida y hasta finales del siglo XV esta situación no comenzó a revertirse, cuando los II condes fueron enterrados en su capilla mayor. ${ }^{53} \mathrm{Es}-$ te hecho parece responder a una incipiente estrategia de acercamiento a la abadía vitense que, sin embargo, no daría sus frutos hasta bien entrada la centuria siguiente con sus sucesores.

Tras diversos conflictos entre la casa religiosa y los Zúñiga, ${ }^{54}$ el control del monasterio pasó a manos de Î́nigo López de Mendoza, hermano del III conde, como abad comendatario en $1516 .{ }^{55}$ Con ello, los condes de Miranda lograban consolidar su papel como señores indiscutibles de todo el entorno, en detrimento del poder que el propio

46 LLAGAS, Ángela de las, 1923, p. 56.

47 AHPBu, Prot. 10721, fol. 466. Hija de Pedro de Zúñiga, futuro marqués de Aguilafuente.

${ }^{48}$ AHPBu, Prot. 5251, fols. 86-93. Hija del IV conde de Miranda.

49 AHPBu, Prot. 5254, fols. 447, 455-457. Hija del I marqués de Santa Cruz.

50 AHPBu, Prot. 5259/6, fols. 25-25v.

${ }^{51}$ AHPBu, Prot. 5256, fols. 68-70; Prot. 10721, fols. 251-252.

52 GUTIÉRREZ BAÑOS, Fernando, 1997, pp. 133-138; 2001, 16, pp. 255-285; LÓPEZ DE GUEREÑO SANZ, María Teresa, 1997, I, pp. 252-263.

${ }^{53}$ AHN [Archivo Histórico Naciona], Clero Regular-Secular, leg. 1390, nº 7.

${ }^{54}$ PERIBÁÑEZ OTERO, Jesús G., 2016, pp. 219-221.

55 VELASCO Y SANTOS, Miguel, 1861, pp. 100-101. 
monasterio había tenido durante la Edad Media. Este hecho, además, les permitiría iniciar una profunda transformación que buscó eliminar la identidad medieval de este establecimiento religioso, ${ }^{56}$ emprendiendo la construcción de nuevos espacios. Don Íñigo, consciente del valor que la arquitectura había representado para sus antepasados $y$, en especial, para sus abuelos, los II condes de Haro, ${ }^{57}$ contribuyó a la renovación de los elementos más notables del antiguo edificio, testimoniando así la dependencia de la casa al linaje de los Zúñiga.

Una de las primeras medidas consistió en el derribo del antiguo claustro románico para levantar una elegante estructura regular cubierta por bóvedas de terceletes. ${ }^{58}$ La transformación se completaría con la instalación de una bella portada de acceso al templo que debe relacionarse con la presencia de Felipe Bigarny en el monasterio a finales de la década de $1530,{ }^{59}$ en el marco de otra serie de actuaciones que, promovidas por los Zúñiga, tuvieron como objeto la villa de Peñaranda de Duero. ${ }^{60}$ Dicha portada se relaciona con los sepulcros del cercano monasterio jerónimo de Espeja, realizados por el borgoñón poco después, como ya apuntó la profesora Redondo Cantera. ${ }^{61}$

Sin embargo, la modificación más importante que experimentaría el edificio en este tiempo sería la construcción de la espléndida capilla mayor que vendría a sustituir a la cabecera románica por ser "...edifiçio muy antiguo y ansí también [...] pequeña y oscura...". ${ }^{62}$ La fábrica que se llevaría a cabo convertiría su poderoso volumen en un referente dentro del complejo monástico, modificando su perfil medieval y dotándolo de una nueva identidad.

La decisión de levantar una obra con la que simbolizar el poder familiar suponía un cambio sus-

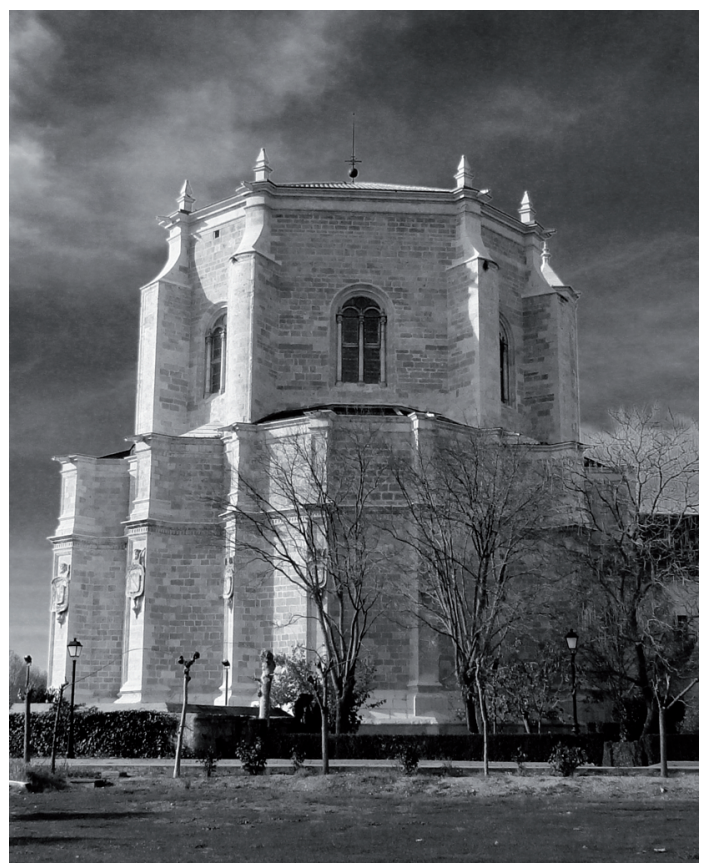

Fig. 3. Cabecera de la iglesia del monasterio de Santa María de La Vid (Burgos). Fotografía del autor.

tancial en la consideración del monasterio y del propio linaje, y se unía a un proceso de renovación más amplio que pretendía, en última instancia, identificar esta fundación con los condes de Miranda. Por ello, don Íñigo inició también la construcción de un puente sobre el río Duero que permitiría comunicar La Vid con Peñaranda de Duero, ${ }^{63}$ configurando un eje viario que uniría los principales hitos arquitectónicos levantados por los Miranda y a los que se dotaba de un nuevo valor territorial, ${ }^{64}$ materializando, de este modo, la dependencia del monasterio al linaje de los Zúñiga.

\footnotetext{
56 ALONSO RUIZ, Begoña, 2003b, p. 46.

57 Sobre esta práctica, ALONSO RUIZ, Begoña, 2014, pp. 227-228.

58 ZAPARAín YÁÑEZ, María José, 1994, pp. 97-98. LÓPEZ DE GUEREÑO SANZ, María Teresa, 1997, I, p. 246.

59 RíO DE LA HOZ, 2001, pp. 322, 325-326. ALONSO RUIZ, Begoña, 2003b, p. 49.

60 Resultan esclarecedores los datos aportados recientemente por VASALLO TORANZO, 2019, 145-160, que constatan los diferentes encargos que recibió el borgoñón por parte de los condes de Miranda, entre ellos lo referido al retablo mayor de la desaparecida iglesia de San Miguel, dado por desaparecido y del que, muy posiblemente, procedan los restos escultóricos conservados en la colegiata peñarandina.

61 REDONDO CANTERA, María José, 2003, p. 297.

62 AHN, Clero Regular-Secular, leg. 1390, n 4. Sobre el edificio románico, vid. HERNANDO GARRIDO, José Luis, 2002, pp. 29092917; 2008, pp. 293-319.

63 VELASCO Y SANTOS, Miguel, 1861, pp. 104 y 106.

64 IGLESIAS ROUCO, Lena S.; ZAPARAÍN YÁÑEZ, María José, 2002, pp. 90-92. ZAPARAÍN YÁÑEZ, María José, 2004, p. 182.
} 
Los primeros pasos en la construcción de la capilla todavía resultan desconocidos, si bien resulta indudable su deuda respecto a las construcciones promovidas por los Velasco en el contexto burgalés. Por ello, puede sospecharse que íñigo López de Mendoza fue el ideólogo de este espacio ${ }^{65}$ pues, a lo largo de su vida, hizo numerosos guiños a su ascendencia materna, de la que se sentía especialmente orgulloso. ${ }^{66}$ Con esta capilla, no solo lograba configurar un lugar preeminente en el que situar su tumba, sino también un modo de perpetuar su legado y exaltar el linaje del que descendía.

Por ello, es probable que don Íñigo lograra persuadir a su hermano, el III conde de Miranda, para que le ayudara a hacer posible tan ambicioso proyecto. A don Francisco le debió seducir la idea de construir un gran espacio de uso funerario a semejanza de los de su familia materna pero, sobre todo, con la intención de materializar su auténtica autoridad a través de una construcción con la que hacer explícita la grandeza del linaje que estaban consolidando. Los dos hermanos entendieron que el proyecto debía sumar las fuerzas de ambos y, por este motivo, dividieron el coste de su construcción, señalando que "...como se haze la capilla a costa de entrambos, mytad por mytad, que también las armas se pongan mezcladas...". ${ }^{67}$ Además, el conde, consciente de la obligación moral que suponían los valores del linaje, mani- festó junto a su esposa la intención de enterrarse en la nueva capilla, ya que en ella "...están nuestros antecesores enterrados y do hemos de estar nosotros..."68 (Fig. 4).

Lamentablemente, los datos referidos a las primeras fases de las obras son contradictorios y únicamente se puede apuntar que en vida de sus promotores apenas se había levantado parte de los muros perimetrales. ${ }^{69}$ Sin embargo, su estructura responde, como ya apuntó por primera vez Weise, ${ }^{70}$ al modelo implementado por el linaje de los Velasco para sus capillas funerarias y, por ello, pasaba a constituir un eslabón más en la larga serie de espacios centralizados cuya tipología arquitectónica evocaba la continuidad del legado familiar. ${ }^{71}$ Sin embargo, su autoría resulta controvertida, ${ }^{72}$ más allá de la convincente vinculación con Juan Gil de Hontañón que apuntó la doctora Alonso Ruiz. ${ }^{73}$

En lo que respecta al diseño de las sepulturas, los dos hermanos acordaron "...que cada uno pague la suya...",74 aunque sus propuestas son muy distantes y el planteamiento de sus últimas voluntades revela unos intereses diferenciados, seguramente motivados por la propia trayectoria vital de cada uno de ellos. Don Íñigo, en su testamento, fechado en 1535, mandaba que su cuerpo fuera enterrado en un convento franciscano, pero con la condición

65 PORRAS GIL, Concepción, 2003, pp. 138-141. ALONSO RUIZ, Begoña, 2005, pp. 142-147.

${ }_{66}$ Prueba de ello es la elección de su propio nombre, en recuerdo a su bisabuelo, el I marqués de Santillana, siguiendo una dinámica propia de la nobleza de este momento. Sobre ello, ALONSO RUIZ, Begoña, 2012, p. 228.

${ }^{67}$ AHNob, Frías, c. 888, d. 11, fol. 18. ACBu [Archivo de la Catedral de Burgos], ACC-48, nº 15, fol. 2v. Recogido, entre otros, en CADIÑANOS BARDECI, Inocencio, 1988, p. 24; ALONSO RUIZ, Begoña, 2003b, p. 47. En el exterior se alternan los escudos de don Íñigo y don Francisco, sostenidos respectivamente por ángeles y salvajes. Al interior, dos grandes escudos a ambos lados del crucero, en los que se incorpora el retrato de los dos hermanos. DOMínGUEZ CASAS, Rafael, 2003, pp. 249-252.

${ }^{68}$ AHNob, Frías, c. 888, d. 11, fol. 18.

${ }^{69}$ ALONSO RUIZ, Begoña, 2003b, p. 48.

70 WEISE, Georg, 1933, pp. 21-22.

71 ALONSO RUIZ, Begoña, 2005, pp. 132-137. PAULINO MONTERO, Elena, 2014, p. 126. Sobre el uso del modelo centralizado en Burgos, vid. TORRES BALBÁS, Leopoldo, 1952, p. 302. ALONSO RUIZ, Begoña, 2003a, pp. 149-170. MARTíN MARTíNEZ DE SIMÓN, Elena, 2013, pp. 273-287.

72 Generalmente se ha venido aceptando que el diseño corresponde a un desconocido maestro llamado Sebastián de Oria, en base a la confusa referencia publicada en LLAGUNO Y AMÍROLA, Eugenio, 1829, II, p. 19. Así lo han señalado, entre otros, CAMÓN AZNAR, José, 1945, I, pp. 85-86; CHUECA GOITIA, Fernando, 1953, pp. 68-69; IBÁÑEZ PÉREZ, Alberto C., 1999 , p. 32. Otros autores, sin embargo, han apuntado que, posiblemente, fue trazada por Juan de Rasines: WEISE, Georg, 1933, pp. 21-22; MARÍAS, Fernando, 1989, p. 126. GÓMEZ MARTíNEZ, Javier, 1998, pp. 68-69. Incluso, se ha señalado la posibilidad de que fuera Bigarny quien diseñara este ámbito arquitectónico: RíO DE LA HOZ, Isabel del, 2001, pp. 322, 325-326.

${ }_{73}$ ALONSO RUIZ, Begoña, 2003b, pp. 46-49. Aparte de las relaciones de este arquitecto con la familia Velasco, se ha apuntado la conexión de la planta del monasterio vitense con uno de los dibujos que recoge Simón García en el Compendio de Architectura y Simetría de los templos, tomado de Rodrigo Gil de Hontañón, conservado en la BNE [Biblioteca Nacional de España], Mss/8884, fol. 7v. Entre otros, HOAG, John D., 1985, pp. 23-25. ALONSO RUIZ, Begoña, 2003b, p. 52.

${ }^{74}$ Así queda consignado en los testamentos de los dos hermanos, el del conde (conjunto con su esposa, María Enríquez de Cárdenas) en AHNob, Frías, c. 888, d. 11, fol. 17v, y el del cardenal en ACBu, ACC-48, n 15, fols. 1v-2. El de los condes, de 1533, permanece inédito, mientras que el de don Íñigo, de 1535, fue transcrito a partir de un traslado del mismo en GARCíA RÁMILA, Ismael, 1958, pp. 67-82. 
de que "...lo más presto que los testamentarios pudieren, me agan llebar a La Bid [...] y dexando el enterramiento donde están mis padres para los herederos de nuestra casa, hagan my sepoltura en la pared donde está señalada, adonde pondrán mi cuerpo y harán un vulto de alabastro o de lo que mejor paresciere a los testamentarios...". ${ }^{75}$ Por su parte, su hermano, Francisco de Zúñiga, y su cuñada, doña María, habían declarado su intención de enterrarse "...en sendas sepolturas juntas, detrás de las del conde don Pedro y condesa doña Catalina de Mendoça, su muger...", limitándose a colocar unas sencillas losas de piedra en las que figuraran sus nombres y la fecha de su fallecimiento. ${ }^{76}$

Sin embargo, las mandas testamentarias no se limitaron a la construcción de la capilla mayor y a la definición de sus enterramientos, sino que en ellas se prestó especial atención a su dotación a través de ricas piezas de orfebrería e importantes ornamentos. ${ }^{77}$ Don Íñigo destinó al monasterio varios conjuntos de plata, aunque el legado más significativo estaba formado por diversas piedras preciosas, como "...el çafir del Cardenal e otro pequeño çafir y un diamante ochabado..." que se destinarían a "...algún cáliz rico...". ${ }^{78}$ Los condes, por su parte, legarían un rico ajuar litúrgico en el que, aparte de algunas piezas de su propiedad, se añadirían otras de nueva realización, siguiendo en todas ellas las mismas características formales para "...que corresponda lo uno con lo otro...". ${ }^{79}$

Las ropas litúrgicas ocuparon un puesto significativo entre el resto de legados y, por ello, los condes quisieron destinar al monasterio un "...ornamento negro de damasco [...] para que esté en nuestra capilla y se digan con él las misas de requien por nuestras almas y de nuestros anteçesores..." así como un "...brocado de pelo..." que debía emplearse para realizar "...un ornamento rico [...] en que aya frontal y capa, y casulla, y almáticas con sus cenefas, y que las dichas cenefas de la capa y casulla sean bordadas de imaginería...". ${ }^{80}$

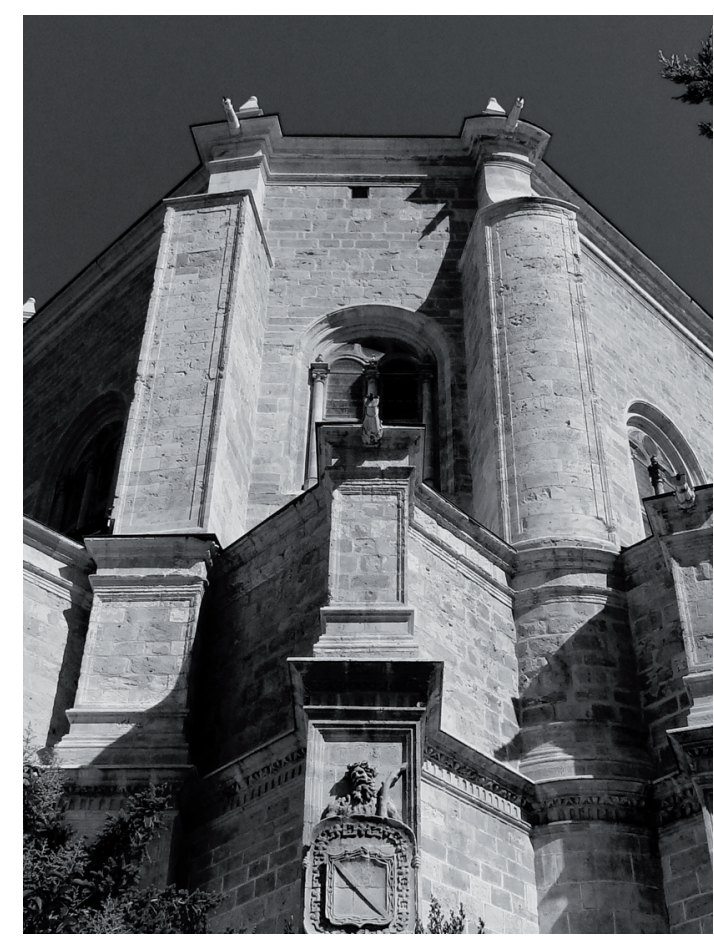

Fig. 4. Detalle de la cabecera de la iglesia del monasterio de Santa María de La Vid (Burgos). Fotografía del autor.

La preocupación personal de don Îñigo disponía también las bases que debían regir el devenir del monasterio premonstratense en el futuro, identificando su actitud constructiva con su propia dimensión intelectual, al igual que sucede con otros contemporáneos. ${ }^{81}$ En su testamento, en el que sentó las bases del futuro Colegio de San $\mathrm{Ni}$ colás de la capital burgalesa, 82 mostró su preocupación por la formación de los religiosos en La Vid, especificando que "...los lybros que tuvyere se repartan entre don Pedro y don Gaspar, mys sobrinos, con que después de sus días vengan al monasterio de La Vid..." 83 para servir a los premonstratenses.

75 ACBu, ACC-48, n 15, fols. 1v-2. Recogido también en ALONSO RUIZ, Begoña, 2003b, p. 47.

76 AHNob, Frías, c. 888, d. 11, fol. 6.

77 ACBu, ACC-48, $n^{\circ} 15$, fol. 11v.

78 ACBu, ACC-48, n 15, fol. 11v. Su mayordomo, Juan Núñez, en su testamento fechado en 1546, renueva el mandato para hacer este cáliz. AHN, Clero Regular-Secular, leg. 1390, Testamento de Juan Núñez (15/08/1546).

79 AHNob, Frías, c. 888, d. 11, fol. 9v.

80 AHNob, Frías, c. 888, d. 11, fols. 9-10.

81 BOUZA, Fernando, 2003, p. 126.

82 Entre otros, LÓPEZ MATA, Teófilo, 1929, pp. 499-507. IBÁÑEZ PÉREZ, Alberto C., 1977, pp. 250-261. PORRAS GIL, Concepción, 1997, pp. 349-358. ALONSO RUIZ, Begoña, 2003a, pp. 253-256.

83 ACBu, ACC-48, n 15, fol. 7. 
Pese a sus propósitos, los dos promotores fallecieron antes de poder ver concluidas las obras -don Íñigo en 1535 y don Francisco al año siguiente- y sus cuerpos fueron trasladados al convento franciscano de La Aguilera de forma provisional hasta que pudieran ser enterrados en la capilla vitense. ${ }^{84}$ La construcción de esta pasará a un segundo plano y la propia viuda del III conde se apartará conscientemente del proyecto en favor de una nueva iniciativa que, en solitario, emprendería en Peñaranda de Duero, consistente en la construcción, apenas tres años después de la muerte de su esposo, de un gran templo frente al palacio familiar, que terminará siendo edificado bajo un diseño de Rodrigo Gil de Hontañón. ${ }^{85}$

El nuevo propósito entraba en conflicto con el papel que don Francisco había planteado para el monasterio e incumplía los acuerdos que el matrimonio había fijado en su testamento de 1533. En ese momento doña María había suscrito ser enterrada en La Vid, junto a su esposo, ${ }^{86}$ pero el proyecto que estaba emprendiendo nacía con la idea de cobijar su propia tumba, como declararía en el testamento que redactó en $1544 .^{87}$

Mientras tanto, las obras de La Vid sufrieron un importante cambio a principios de la nueva década, posiblemente derivados de las peticiones del IV condestable de Castilla, Pedro Fernández de Velasco, como responsable de cumplir el testamento de Íñigo López de Mendoza. El 1 de junio de 1542 se reunió en La Vid un grupo de reconocidos maestros -Juan y Pedro de Rasines, Juan de Vallejo, Juan Vizcaíno y Bartolomé de Pierredondapara ver "...todo el edificio de cantería nuevo que al presente estaba hecho en la capilla y cuerpo de la yglesia..." y estudiar "...lo que resta de azer..." para que se pudiera "...acabar en perfeción y quede en la seguridad y según conviene a semejante edificio..." ${ }^{88}$

En el informe que redactaron tras su visita dan a entender que la capilla no se estaba llevando a cabo con la suficiente solidez y que, por ello, era necesario reforzar los arcos que debían sustentar la bóveda, incorporar un nuevo estribo o arbotantes que aligeraran el peso de esta. ${ }^{89}$ Entonces se estaba iniciando la realización de las trompas, para las que piden que se empleen "...muy buenas piezas, de muy buen grueso [...] conforme a la traza y como están principiados...". ${ }^{90}$ Además, señalan que se modifique la escalera de caracol, replanteándose en este momento toda su estructura. Asimismo, indicaron algunos cambios que afectarían al planteamiento decorativo de la capilla, añadiendo capiteles renacentistas a las diferentes columnillas y aportando la idea de que se modificara la cubierta de la cabecera.

Hasta ese momento se contemplaba que esta estuviera "...cerrada de sus branchas y clabes conforme a como está señalado en un papel...", pero los maestros opinan que sería factible optar por "...una venera, porque se mostrará bien..." si así lo consideraran "...los señores y maestros que dello tienen cargo..."91 que, finalmente, aceptaron el cambio. Este detalle supone una modificación sustancial del diseño original y cambiaba por completo la comprensión del espacio interior de la capilla, adaptándolo a un lenguaje renovado que poco tenía que ver con la concepción tardogótica inicial del conjunto. ${ }^{92}$

La elegante venera, que se pone en relación con otras realizadas en el contexto burgalés ${ }^{93}$ tendría, en la espléndida cubierta de la capilla de Santiago de la catedral de El Burgo de Osma, su eco más próximo, como acertadamente apuntó el profesor Martínez Frías. ${ }^{94}$ Además, aparte de este cambio,

${ }^{84}$ AHN, Clero Regular-Secular, leg. $1390, n^{\circ} 7$.

85 Entre otros, IBÁÑEZ PÉREZ, Alberto C., 1989, pp. 398-401.

${ }^{86}$ AHNob, Frías, c. 888, d. 11, fol. 18.

87 ESCORIAL ESGUEVA, Juan, 2017, p. 482.

${ }^{88}$ AHN, Clero Regular-Secular, leg. 1390. Capítulos de la bisitaçión de la obra de la capilla. Esta noticia ya aparecía recogida en LOPERRÁEZ CORVALÁN, Juan, 1788, II, pp. 191-192. LLAGUNO Y AMÍROLA, Eugenio, 1829, I, p. 165; II, p. 19-20. Transcrito en GARCÍA CHICO, Esteban, 1961, pp. 88-91.

${ }^{89}$ En una nueva indicación del 20 de abril de 1547 renuncian a algunos de estos cambios por su dificultad. Cfr. GARCíA CHICO, Esteban, 1961, p. 91.

90 Sin embargo, las trompas seguirían en construcción diez años más tarde. AHN, Clero Regular-Secular, L. 18959, 21/05/1552.

91 GARCÍA CHICO, Esteban, 1961, p. 90.

92 ALONSO RUIZ, Begoña, 2003b, pp. 45-54.

93 Sobre el uso de veneras en el territorio burgalés vid. IBÁÑEZ PÉREZ, Alberto C., 1999, pp. 33-34. POLO SÁNCHEZ, Julio J., 2011, p. 296. Cabe apuntar que en el conocido dibujo del manuscrito de Simón García que se ha relacionado con la capilla vitense aparece dibujada la venera de la cabecera, si bien se plantea sobre una planta semicircular y no poligonal, por lo que no sería descabellado pensar que el propio Rodrigo Gil de Hontañón visitara el monasterio y aportara su parecer sobre la obra, ya que es conocida su vinculación con los hijos de los III condes. Sobre ello, ESCORIAL ESGUEVA, Juan, 2017, p. 482.

${ }^{94}$ MARTínEZ FRÍAS, José María, 1980, p. 91. También en ALONSO RUIZ, Begoña, $2003 b$, p. 54. 
se introducirían cubiertas de casetones en las capiIlas hornacinas que, si bien no aparecen reflejadas en el informe de los maestros, debieron replantearse en este mismo momento, ${ }^{95}$ dotando al conjunto de un lenguaje diferenciado que, aparte de definir una nueva ornamentación, confería al espacio interior de una solidez y solemnidad muy diferentes al modelo que se había definido inicialmente (Fig. 5).

El proceso constructivo debía estar avanzando con cierta celeridad y ello posibilitó que el 21 de enero de 1549, los premonstratenses cedieran al IV conde de Miranda el patronato de la capilla mayor, en atención a "...los grandes benefiçios y buenas obras que aquella casa y monesterio abían rresçivido y rreciben cada día..." del conde y "...de sus pasados señores que fueron de la dicha casa y de los hijos y descendientes della...". La escritura de patronato especificaba que se incluían en él la "...capilla mayor, que esto todo lo que está de la rreja adentro...", permitiendo al conde y a sus sucesores "...enterrar libremente y haçer sus sepolturas [...] poniendo en ellas sus harmas...". ${ }^{96}$

En las décadas siguientes, el IV conde de Miranda y el IV condestable de Castilla ratificaron el compromiso por continuar las obras, ${ }^{97}$ que se mantuvieron bajo la dirección de Pedro de Rasines hasta su fallecimiento, ${ }^{98}$ en tiempos de los VI condes, cuando se debió completar su construcción, como atestigua la fecha que aparece inscrita sobre la venera. Sin embargo, el fin de las obras no supuso la conclusión real de la capilla.

Habría que esperar hasta 1579 cuando se bendijo la iglesia ${ }^{99}$ y se produjo el traslado de los cuerpos del III conde y de su hermano Íñigo López de Mendoza desde La Aguilera, donde habían sido enterrados de forma provisional, mientras se completaba la construcción de su espacio funerario en La Vid. ${ }^{100}$ La nueva capilla pasaba a convertirse en el

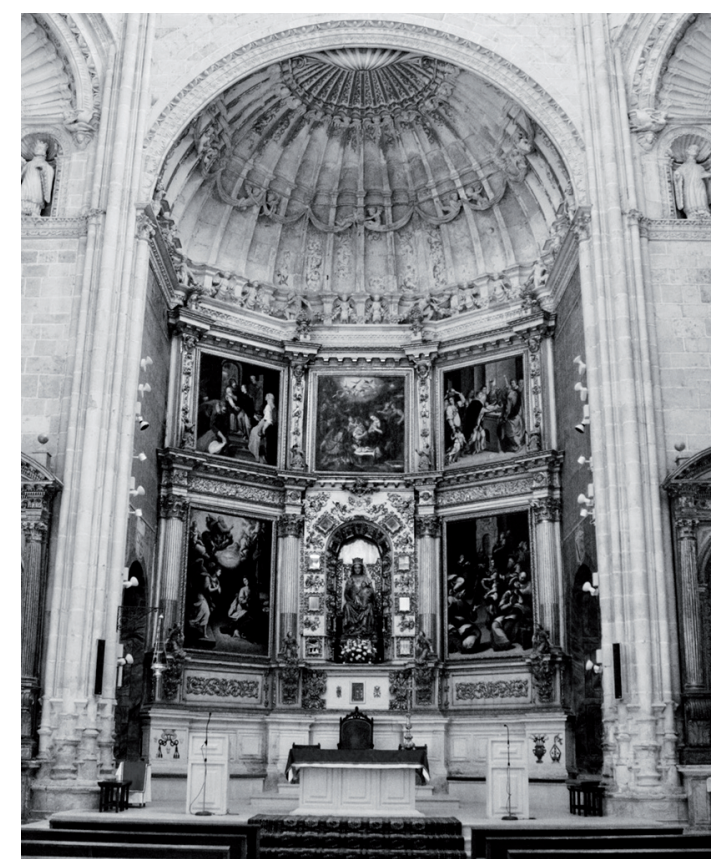

Fig. 5. Capilla mayor de la iglesia del monasterio de Santa María de La Vid (Burgos). Fotografía del autor.

símbolo visible más elocuente de los patronatos familiares, con una significación propia que trascendía los límites del poder temporal de sus fundadores para perpetuar su memoria y hacer presente al resto de sus descendientes del papel que la nobleza debía representar.

El 1 de noviembre de ese mismo año se llevó a cabo una ceremonia en la que los restos de los dos hermanos que habían iniciado las obras -don Francisco y don Íñigo-, de sus padres y del IV conde de Miranda se colocaron en un cenotafio de madera levantado en el centro de la capilla. ${ }^{101}$ Presen-

95 ALONSO RUIZ, Begoña, 2003b, pp. 53-54.

96 AHN, Clero Regular Secular, leg. 1390, n² 2. Escritura de patronato de la capilla mayor. Recogido parcialmente en CADIÑANOS BARDECI, Inocencio, 1988, p. 23.

97 En el Archivo Histórico Nacional se conservan dos libros de cuentas: Libro de quentas de gasto e de reçibo [1552-1562] y Libro de las quentas de la obra de La Bid de gasto y reçibo de este año de MDLXII [1562-1570], (respectivamente, Clero RegularSecular, L. 18959 y leg. 1390). Recogido en VELASCO Y SANTOS, Miguel, 1861, pp. 104-105. También en GARCÍA CHICO, Esteban, 1961, pp. 95-96. CADIÑANOS BARDECI, Inocencio, 1988, pp. 22-29. ALONSO RUIZ, Begoña, 2003a, pp. 284-292. Otras referencias a las obras en AHPBu, Prot. 5251, fols. 273-274.

98 CADIÑANOS BARDECI, Inocencio, 1988, p. 29. ALONSO RUIZ, Begoña, 2003a, pp. 289-292.

99 AHN, Clero Regular-Secular, leg. $1390, \mathrm{n}^{\circ} 6$.

100 AHN, Clero Regular-Secular, leg. 1390, nº 7.

101 ZAPARAÍN YÁÑNEZ, María José; ESCORIAL ESGUEVA, Juan, 2017, pp. 203-223. Después, los cuerpos de los II condes se colocaron en el centro de la capilla, cobijados por una reja de madera, hoy desaparecida. A su izquierda se ubicó la sepultura de IV conde. Los restos del III conde y de su hermano Íñigo pasaron a ocupar sus respectivos huecos a los lados de la capilla mayor. AHN, Clero Regular-Secular, leg. 1390, $n^{\circ} 5,7$. 


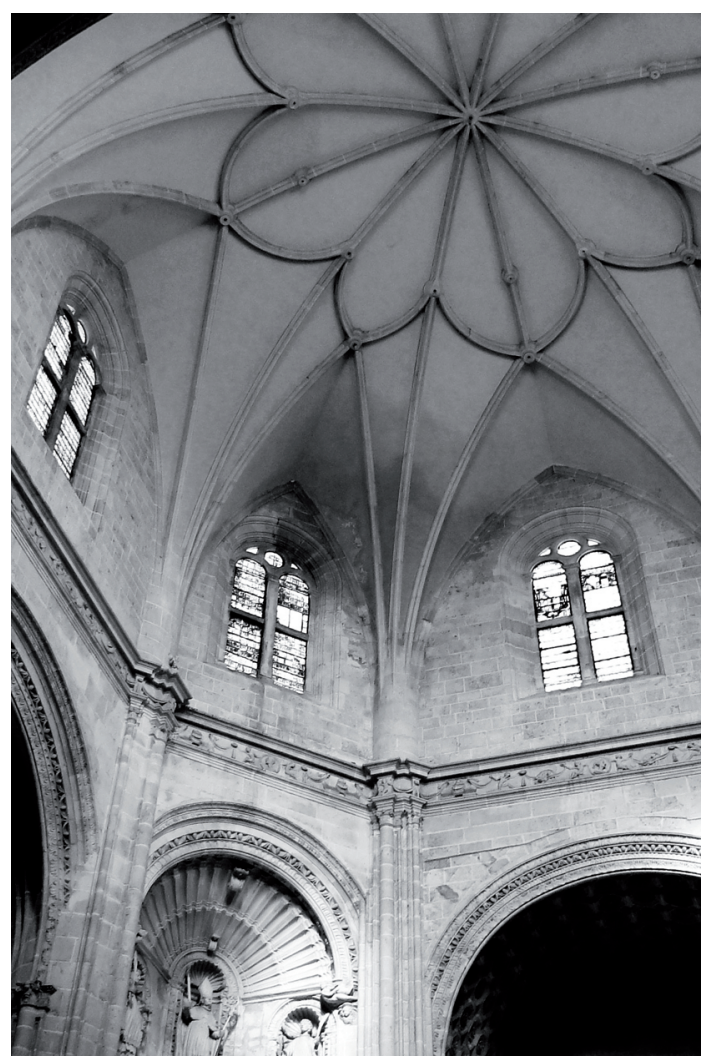

Fig. 6. Detalle de la bóveda de la capilla mayor del monasterio de Santa María de La Vid (Burgos). Fotografía del autor.

senciaron el acto la viuda del V conde y, los entonces titulares, Juan y María de Zúñiga y Avellaneda. ${ }^{102}$ De este modo quedaban congregadas en el mismo espacio cinco generaciones de la casa de Miranda, culminando, así, los propósitos de sus predecesores y renovando su compromiso histórico con la abadía vitense (Fig. 6).

\section{Bibliografía}

ALONSO RUIZ, Begoña. Arquitectura tardogótica en Castilla. Los Rasines. Santander: Universidad de Cantabria, 2003a.

ALONSO RUIZ, Begoña. "De la capilla gótica a la renacentista: Juan Gil de Hontañón y Diego de Siloe en La Vid". Anuario del Departamento de Historia y Teoría del Arte, 2003b, XV, pp. 45-57.

ALONSO RUIZ, Begoña. "Arquitectura y arte al servicio del poder: una visión sobre la casa de Velasco durante el siglo XVI". En: ALONSO RUIZ, Begoña; CARLOS VARONA, María Cruz de; PEREDA ESPESO, Felipe. Patronos y coleccionistas: los condestables de Castilla y el arte (siglos XV-XVII). Valladolid: Universidad de Valladolid, 2005, pp. 121-206.
ALONSO RUIZ, Begoña. "La nobleza en la ciudad: arquitectura y magnificencia a finales de la Edad Media". Studia historica. Historia moderna, 2012, 34, pp. 215251.

ATIENZA LÓPEZ, Ángela. "La apropiación de patronatos conventuales por nobles y oligarcas en la España moderna" en Investigaciones históricas: época moderna y contemporánea, 2008a, 28, pp. 79-116.

ATIENZA LÓPEZ, Ángela. "Patronatos nobiliarios sobre las órdenes religiosas en la España moderna". En: CASTELLANO CASTELLANO, Juan Luis; LÓPEZ-GUADALUPE MUÑOZ, Miguel Luis (eds.). Homenaje a don Antonio Domínguez Ortiz. Granada: Universidad de Granada, 2008b, I, p. 67-82.

ATIENZA LÓPEZ, Ángela. Tiempo de conventos. Una historia social de las fundaciones en la España moderna. Madrid: Marcial Pons Historia, 2008c.

ATIENZA LÓPEZ, Ángela. "Nobleza, poder señorial y conventos en la España moderna. La dimensión política de las fundaciones nobiliarias". En: SARASA SÁNCHEZ, Esteban; SERRANO MARTíN, Eliseo (eds.). Estudios sobre señorío y feudalismo. Homenaje a Julio Valdeón. Zaragoza: Institución Fernando el Católico, 2010, pp. 235-269.

BANGO TORVISO, Isidro. "El espacio para enterramientos privilegiados en la arquitectura medieval española". Anuario del Departamento de Historia y Teoría del Arte, 1992, 4, pp. 93-132.

BOUZA, Fernando. Palabra e imagen en la Corte: cultura oral y visual de la nobleza en el Siglo de Oro. Madrid: Adaba, 2003.

CADIÑANOS BARDECI, Inocencio. "Proceso constructivo del Monasterio de La Vid (Burgos)". Archivo Español de Arte, 1988, LXI, 241, pp. 21-36.

CAMÓN AZNAR, José. La arquitectura plateresca. Madrid: Instituto Diego Velázquez, 1945.

CARAZO LEFORT, Eduardo. "El palacio de los condes de Miranda en Peñaranda de Duero". Academia. Boletín de la Real Academia de Bellas Artes de San Fernando, 1997, LXXXV, pp. 505-544.

CARRIÓN GONZÁLEZ, Luis. Historia documentada del Convento Domus Dei de La Aguilera. Madrid: Ibérica, 1930.

CASTRO Y CASTRO, Manuel de. "Los monasterios de concepcionistas franciscanas en España". Archivo Ibero-Americano, 1991, LI, 203-204, pp. 411-477.

CASTRO Y CASTRO, Manuel de. Teresa Enríquez, la "Loca del Sacramento" y Gutierre de Cárdenas. Toledo: Instituto Provincial de Investigaciones y Estudios Toledanos, 1992

CHUECA GOITIA, Fernando. Arquitectura del siglo XVI [Ars Hispaniae. T. XI]. Madrid: Plus Ultra, 1953.

DOMÍNGUEZ CASAS, Rafael. "Heráldica del arte del Renacimiento. Burgos y el sur provincial". Biblioteca. Estudio e investigación, 2003, 18, pp. 217-262.

ESCORIAL ESGUEVA, Juan. "Arquitectura y edificación en la Ribera del Duero burgalesa (1544-1595): entre la tradición gótica y las formulaciones clasicistas". En: HUERTA, Santiago, FUENTES, Paula; GIL CRESPO, Ignacio J. (coords.). Actas del Décimo Congreso Nacional y Segundo Congreso Internacional Hispanoamericano de Historia de la Construcción. Madrid: Instituto Juan de Herrera, 2017, I, pp. 481-490. 
GARCÍA CHICO, Esteban. "Documentos referentes al Monasterio de Nuestra Señora de La Vid". Boletín del Seminario de Estudios de Arte y Arqueología, 1961, XXVII, pp. 87-102.

GARCÍA RÁMILA, Ismael. El Instituto Nacional de Enseñanza Media Cardenal López de Mendoza de Burgos. Noticias histórico-documentales. Burgos: Diputación Provincial de Burgos, 1958.

GÓMEZ MARTíNEZ, Javier. El gótico español de la Edad Moderna. Bóvedas de crucería. Valladolid: Universidad de Valladolid, 1998.

GUTIÉRREZ BAÑOS, Fernando. Las empresas artísticas de Sancho IV el Bravo. Valladolid, Junta de Castilla y León, 1997.

GUTIÉRREZ BAÑOS, Fernando. "Sancho IV en la Ribera del Duero: el testimonio de su labor de promoción de las artes". Biblioteca. Estudio e investigación, 2001, 16, pp. 255-285;

HERNANDO GARRIDO, José Luis. "La Vid" en Enciclopedia del Románico de Castilla y León. Burgos. Aguilar de Campoo, Fundación Santa María la Real-Centro de Estudios del Románico, 2002, IV, pp. 2909-2917.

HERNANDO GARRIDO, José Luis. "Monasterios cistercienses y premonstratenses en la Ribera del Duero: testimonios arquitectónicos y plásticos". Biblioteca. Estudio e investigación, 2008, 23, pp. 293-319.

HOAG, John D. Rodrigo Gil de Hontañón. Gótico y renacimiento en la arquitectura española del siglo XVI. Madrid: Xarait, 1985.

IBÁÑEZ PÉREZ, Alberto C. Arquitectura civil del siglo XVI en Burgos. Burgos, Caja de Ahorros Municipal de Burgos, 1977.

IBÁÑEZ PÉREZ, Alberto C. "Rodrigo Gil de Hontañón y la iglesia colegial de Peñaranda de Duero (Burgos)". Boletín del Seminario de Estudios de Arte y Arqueología, 1989, LV, pp. 398-401.

IBÁÑEZ PÉREZ, Alberto C. "Arquitectura, escultura, pintura y artes menores del siglo $\mathrm{XVI}$ " en Historia de Burgos III. Edad Moderna (3). Burgos: Caja de Burgos, 1999, pp. 7-196.

IGLESIAS ROUCO, Lena S.; ZAPARAÍN YÁÑEZ, María José. Burgos y sus villas. Arquitectura y paisaje (17501800). Burgos: Caja Círculo de Burgos, 2002.

JIMENO, Pascual Domingo. "La villa ducal de Peñaranda de Duero y sus relaciones con el monasterio franciscano de La Aguilera", Boletín de la Institución Fernán González, 1966, XLV, 166, p. 103.

LAMPÉREZ Y ROMEA, Vicente. "El palacio de los condes de Miranda en Peñaranda de Duero (Burgos)". Boletín de la Sociedad Española de Excursiones, 1912, XX, 2, pp. 146-151.

LLAGAS, Ángela de las. La bella prisionera. Breve compendio histórico de la prodigiosa vida de la venerable madre Beatriz de Silva, ínclita fundadora de la Orden de la Purísima Concepción. Valladolid: Imprenta de L. Miñón, 1923.

LLAGUNO Y AMÍROLA, Eugenio. Noticias de los arquitectos y arquitectura de España desde su restauración. Madrid: Imprenta Real, 1829.

LOPERRÁEZ CORVALÁN, Juan. Descripción histórica del obispado de Osma. Madrid: Imprenta Real, 1788.

LÓPEZ CUÉTARA, José Miguel. "La orden de la Inmaculada Concepción en Burgos. Siglo XVI". En: I Congreso Internacional del Monacato Femenino en España, Portugal y América, 1492-1992. León, Universidad de León, 1993, II, pp. 309-320.
LÓPEZ DE GUEREÑO SANZ, María Teresa. Monasterios medievales premonstratenses. Reinos de Castilla y León. Valladolid, Junta de Castilla y León, 1997.

LÓPEZ MATA, Teófilo. "El colegio de San Nicolás: una fundación docente del siglo XVI". Boletín de la Comisión Provincial de Monumentos Históricos y Artísticos de Burgos, 1929, VIII, 29, pp. 499-507.

MARÍAS, Fernando. El largo siglo XVI. Los usos artísticos del Renacimiento español. Madrid: Taurus, 1989.

MARÍAS, Fernando. "La obra renacentista del claustro de los Caballeros de Santa María la Real de Huerta". En: BANGO TORVISO, Isidro G. (dir.). Monjes y monasterios. El Císter en el medievo de Castilla y León. VaIladolid: Junta de Castilla y León, 1998, pp. 289-295.

MARTÍN MARTÍNEZ DE SIMÓN, Elena. "Un modelo funerario de la escuela burgalesa. Las capillas centralizadas de la segunda mitad del siglo XV en Burgos". Anales de Historia del Arte, 2013, 23, 1, pp. 273-287.

MARTÍNEZ FRÍAS, José María. El gótico en Soria. Arquitectura y escultura monumental. Salamanca: Universidad de Salamanca y Diputación Provincial de Soria, 1980.

MARTÍNEZ MONTERO, Jorge. "La escalera del palacio de los condes de Miranda en Peñaranda de Duero", De arte: revista de historia del arte, 2005, 4, pp. 75-87.

MARTÍNEZ-BURGOS GARCÍA, Palma. Ídolos e imágenes. La controversia del arte religioso en el siglo XVI español. Valladolid: Universidad de Valladolid, 1990.

PAULINO MONTERO, Elena. "Las trayectorias cruzadas de los patronos. Los Velasco y su incorporación a la nueva arquitectura". En: ALONSO RUIZ, Begoña; VILLASEÑOR SEBASTIÁN, Fernando (eds.). Arquitectura tardogótica en la Corona de Castilla: trayectorias e intercambios. Santander: Universidad de Sevilla-Universidad de Cantabria, 2014, pp. 111-132.

PAYO HERNANZ, René Jesús; MATESANZ DEL BARRIO, José. La Edad de Oro de la Caput Castellae. Arte y sociedad en Burgos. 1450-1600. Burgos: Dossoles, 2015.

PELLICER DE OSSAU Y TOVAR, José. Justificación de la grandeça y cobertura de Primera Clase en la casa y Persona de Don Fernando de Zúñiga, noveno conde de Miranda. Madrid: Diego Díaz de la Carrera, 1668, fol. $59 \mathrm{v}$.

PEREDA ESPESO, Felipe. "Magnificencia, también propaganda. Las capillas funerarias en la Península Ibérica durante la baja Edad Media". En: ÁLVAREZ PALENZUELA, Vicente Ángel (coord.). III Jornadas de Cultura Hispano-Portuguesa. Interrelación cultural en la formación de una mentalidad. Siglos XII al XVI. Madrid: Universidad Autónoma de Madrid, 1999, pp. 313-324.

PEREDA ESPESO, Felipe. "Mencía de Mendoza (+1500). Mujer del I condestable de Castilla. El significado del patronazgo femenino en la Castilla del siglo XV". En: ALONSO RUIZ, Begoña; CARLOS VARONA, María Cruz de; PEREDA ESPESO, Felipe. Patronos y coleccionistas: los condestables de Castilla y el arte (siglos XV-XVII). Valladolid: Universidad de Valladolid, 2005, pp. 9-119.

PERIBÁÑEZ OTERO, Jesús G. "El control del territorio en la Ribera del Duero en la Baja Edad Media". Biblioteca. Estudio e investigación, 2010, 25, pp. 39-65.

PERIBÁÑEZ OTERO, Jesús G. Villas, villanos y señores en el tránsito hacia la modernidad. La Ribera del Duero burgalesa a finales de la Edad Media. Valladolid: Universidad de Valladolid, 2016. 
POLO SÁNCHEZ, Julio J. "El modelo hallenkirchen en Castilla". En: ALONSO RUIZ, Begoña (coord.). La arquitectura tardogótica castellana entre Europa y América. Madrid: Sílex, 2011, pp. 281-312.

PORRAS GIL, Concepción. "El colegio de San Nicolás en Burgos. Reflexiones a su estudio". Boletín del Seminario de Estudios de Arte y Arqueología, 1997, LXIII, pp. 349-358.

PORRAS GIL, Concepción. "Estética y humanismo en la familia Zúñiga Avellaneda". Biblioteca. Estudio e investigación, 2003, 18, pp. 117-142.

QUINTANILLA RASO, María Concepción. "Élites de poder, redes nobiliarias y monarquía en la Castilla de fines de la Edad Media" en Anuario de Estudios Medievales, 2007, 37, II, pp. 958-971.

REDONDO CANTERA, María José. "Esculturas del Renacimiento en las aguas durolenses". Biblioteca. Estudio e investigación, 2003, 18, pp. 281-314.

RíO DE LA HOZ, Isabel del. El escultor Felipe Bigarny (h. 1470-1542). Valladolid, Junta de Castilla y León, 2001.

RUIZ-GÁLVEZ PRIEGO, Estrella. "La Inmaculada, emblema de la firmeza masculina", Arenal: revista de historia de mujeres, 2006, XIII, 2, pp. 291-310.

RUIZ-GÁLVEZ PRIEGO, Estrella. "Sine Labe. El Inmaculismo en la España de los siglos XV a XVII: la proyección social de un imaginario religioso", Revista de Dialectología y Tradiciones Populares, 2008, LXIII, 2, pp. 197-241.

SORIA MESA, Enrique. La nobleza en la España moderna. Cambio y continuidad. Madrid: Marcial Pons, 2007.

TORRES BALBÁS, Leopoldo. Arquitectura gótica [Ars Hispaniae, T. VII]. Madrid: Plus Ultra, 1952.

URQUÍZAR HERRERA, Antonio. "La dureza y constancia del papel. Los usos artísticos en la memoria escrita de la nobleza española de la Edad Moderna" en Trocadero. Revista de historia moderna y contemporánea, 2007, 19, pp. 69-93.

VASALLO TORANZO, Luis. "Felipe Bigarny a la luz de su testamento e inventario de bienes". Archivo Español de Arte, 2019, XCII, 366, pp. 145-160.

VELASCO Y SANTOS, Miguel. Índice de los documentos procedentes de los monasterios y conventos suprimidos que se conservan en el Archivo de la Real Academia de la Historia. Sección Primera. Castilla y León.
Tomo I. Monasterios de Nuestra Señora de La Vid y San Millán de la Cogolla. Madrid: Imprenta de Manuel Galiano, 1861.

WEISE, Georg. Studien zur spanischen architektur der Spätgotik. Reutlingen, Gryphius, 1933.

YARZA LUACES, Joaquín. "La capilla funeraria hispana en torno a 1400". En: NÚÑEZ RODRÍGUEZ, Manuel; PORTELA SILVA, Ermelindo (coords.). La idea y el sentimiento de la muerte en la historia y en el arte de la Edad Media. Santiago de Compostela: Universidade de Santiago de Compostela, 1988, pp. 67-91.

ZAPARAÍN YÁÑEZ, María José. El monasterio de Santa María de La Vid. Del medievo a las transformaciones arquitectónicas de los siglos XVII y XVIII. Madrid: Religión y Cultura, 1994.

ZAPARAÍN YÁÑEZ, María José. "Poder y magnificencia. Las residencias señoriales". Biblioteca. Estudio e investigación, 2004, 19, pp. 175-218.

ZAPARAÍN YÁÑEZ, María José. "Con otros ojos. La promoción nobiliar femenina en la Ribera burgalesa del Duero. Siglos XVI y XVII". Biblioteca. Estudio e investigación, 2013, 28, pp. 261-298.

ZAPARAÍN YÁÑEZ, María José. "Del rigorismo ascético a la apoteosis barroca. La elaboración de la imagen de fray Pedro Regalado hasta su beatificación". Biblioteca. Estudio e investigación, 2016, 31, pp. 219-259.

ZAPARAÍN YÁÑEZ, María José; ESCORIAL ESGUEVA, Juan. "María de Zúñiga y Avellaneda, VI condesa de Miranda. Linaje, promoción artística y devoción en los umbrales del Barroco". En: RODRÍGUEZ MIRANDA, María del Amor; PEINADO GUZMÁN, José Antonio (coords.). El Barroco: universo de experiencias. Córdoba: Hurtado Izquierdo, 2017, pp. 203-223.

ZAPARAÍN YÁÑEZ, María José; ESCORIAL ESGUEVA, Juan. "Los VI condes de Miranda y sus relaciones artísticas con Italia: poder, memoria y piedad. Aproximación a su estudio". En: HOLGUERA CABRERA, Antonio; PRIETO USTIO, Ester; URIONDO LOZANO, María (coords.). Coleccionismo, mecenazgo y mercado artístico: su proyección en Europa y América. Sevilla: Universidad de Sevilla, 2018, pp. 618-633.

ZAPARAÍN YÁÑEZ, María José; ESCORIAL ESGUEVA, Juan. "Gusto y promoción en el contexto cortesano. Los condes de Miranda en el tránsito a la Contemporaneidad", De Arte, 2019, 18, pp. 135-155. 